\section{Psykoanalytisk perle}

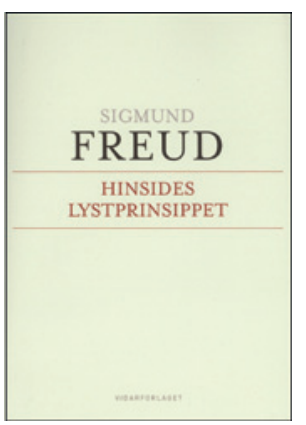

Sigmund Freud

Hinsides lystprinsippet

121 s. Oslo: Vidarforlaget, 2011. Pris NOK 299

ISBN 978-82-7990-077-1
Det er bemerkelsesverdig at det kommer to bokutgivelser med oversatte Freud-tekster i 2011. Den ene er Mellom psykoanalyse og litteratur, utgitt i Gyldendals klassikerserie. Den andre er det 80 sider lange essayet Hinsides lystprinsippet, bestående av sju kapitler, som regnes blant de mest filosofiske av Freuds verker. Det ble publisert i 1920, men har ikke vært oversatt til norsk tidligere. Dette må bety at interessen for Freud strekker seg langt utenfor psykiaternes og psykologenes rekker. Riktignok er psykoanalysen høyst levende ved to av våre universiteter og tre av våre spesialiserte videreutdanningsinstitusjoner. Men også innen litteraturvitenskap, filosofi og kunstvitenskap er det stor interesse for psykoanalytisk teori, både internasjonalt og i Norge.

Hinsides lystprinsippet representerer Freuds revisjon av en del sentrale teoretiske oppfatninger. Bakgrunnen er bl.a. den første verdenskrigs grusomheter og erfaringen med de traumatiske krigsnevrosene, som det ble kalt. Et personlig motiv kan også være at datteren Sophie døde av spanskesyken, 26 år gammel, i januar 1920, og etterlot seg to små barn. I løpet av krigsårene skrev Freud også fem metapsykologiske (dvs. teoretiske) artikler, som til sammen bar bud om behovet for en teoretisk revisjon.

Frem til dette tidspunktet postulerte Freud at de to store driftstendensene, seksualdriften og selvoppholdelsesdriften, var underordnet det han kalte lystprinsippet og dets videreføring i realitetsprinsippet (en modifikasjon av lystprinsippet). Lystprinsippet i Freuds metapsykologi var ganske tvetydig, idet han knyttet det til forestillingen om reduksjon av spenning, en arv fra antikkens filosofi (Platon og Aristoteles), stikk i strid med vår intuitive oppfatning av lyst som spenning.

Nå erkjente Freud at det var noen viktige fenomener som ikke kunne forklares ut fra lystprinsippet. For det første var det de repeterende traumatiske drømmene som var så karakteristisk for krigsnevrosene. I Drømmetydningen hevdet han jo at alle drømmer springer ut fra et ubevisst ønske og dermed er ønskeoppfyllende. Den beste forklaringen han kunne gi når det gjaldt de traumatiske drømmene, var at de forberedte psyken på å mestre traumet post facto.

Barns repeterende lek - han beskrev sin dattersønns «borteborte-titt-titt»-lek med en trådsnelle som utgangspunkt - kunne forstås som en måte å mestre separasjon og tap på, i det konkrete tilfellet morens død i spanskesyken.

Også i noe så sentralt som pasientens tendens til å repetere tidligere relasjoner i overføringen til analytikeren, var gjentakelsen av det ulystbetonte - med potensial for mestring, dvs. forandring - det grunnleggende.

Gjentakelsestvangen kan altså ikke forklares ut fra lystprinsippet, det krever en forklaring bakenfor dette. I kapittel IV og V forsøker Freud å nærme seg et svar ved å hevde at et sterkt traume punkterer det «stimuliskjoldet» (Reizschütz) som psyken beskytter seg bak, og dermed blir psyken offer for påvirkning av krefter som er mer primitive enn lystprinsippet. Vi vil i dag kanskje assosiere til frysreaksjonen, kjent fra nevrobiologi.

I kapittel VI og VII beveger han seg inn i de store «metafysiske» spørsmålene. Freuds forfatterskap har et enormt spenn fra de kliniske skriftene like til de største temaene om menneskets psyke i biologisk og kulturhistorisk perspektiv. I den nye driftsteorien er seksual- og selvoppholdelsesdriftene representant for Eros, de sammenbindende og byggende kreftene. Som deres motsetning står dødsdriften, som representerer den biologiske tendensen henimot stillstand og død.

I dødsdriften ser Freud en forklaring ikke bare på repetisjonstvangen, men også på klinisk viktige fenomener som sadisme (og masochisme). Han tenderer til å se masochismen som et primært fenomen, med sadismen som sin avledning, men legger ikke skjul på at dette er et spekulativt og langt på vei uforklarlig fenomen. Skal dødsdriften oppfattes som et biologisk prinsipp, et psykologisk grunnfenomen, eller en naturfilosofisk spekulasjon? Dette var allerede i Freuds levetid et svært kontroversielt spørsmål.

Eivind Tjønneland har forsynt utgivelsen med en fyldig, detaljert redegjørelse for diskusjonen om dødsdriften. Et forenklet bilde kan være følgende: Mange av Freuds elever forkastet ideen om dødsdriften. Det gjaldt bl.a. Wilhelm Reich (1897-1957) og Otto Fenichel (1897-1946) som gjennom sitt eksil i Norge før krigen øvet sterk innflytelse her. Den sterkt toneangivende amerikanske ego-psykologien, formet av emigrantene Heinz Hartmann (1894-1970), Ernst Kris (1900-57) og Rudolph Loewenstein (1898-1976), omtolket i 1949 dødsdriften til egentlig å være en betegnelse på aggresjonsdriften, som motstykke til seksualdriften.

Den tradisjonen som holdt fast på Freuds begrep dødsdrift, var retningen fra Melanie Klein (1882-1960), som har vært så innflytelsesrik i England og Latin-Amerika. Denne retningen, en gang betraktet som kjettersk, har vunnet stor innflytelse de siste tiårene, men begrepet dødsdriften som drift, er sterkt «avmytologisert» hos dagens tilhengere av Klein.

I Frankrike foregikk det en sterk renessanse for nylesning av Freud fra 1950-årene av, i utgangspunktet preget av Jacques Lacan (1901-81), en kultfigur i fransk kulturliv. Mange forfattere har tolket begrepet dødsdrift på ulike måter i den franske psykoanalysen. Dette vil føre for langt å gå inn på her.

Jeg vil anbefale denne boken for alle som er opptatt av psykologi, kulturhistorie og litteratur. Det er en stilistisk perle og vil gi mange overraskende opplevelser for alle de som tror de allerede har forstått, forkastet eller fordøyd Freuds bilde av det moderne mennesket.

\section{Svein Haugsgjerd}

Oslo universitetssykehus 